\title{
A Review on the Catalytic Hydrogenation of Bromate in Water Phase
}

\author{
Jose Luis Cerrillo (D) and Antonio Eduardo Palomares *(D) \\ Instituto de Tecnología Química (CSIC-Universitat Politècnica de València), Camino Vera s.n., \\ 46022 Valencia, Spain; jose.cerrilloolmo@kaust.edu.sa \\ * Correspondence: apalomar@iqn.upv.es; Tel.: +34-963-877-800
}

Citation: Cerrillo, J.L.; Palomares, A.E. A Review on the Catalytic Hydrogenation of Bromate in Water Phase. Catalysts 2021, 11, 365. http:/ / doi.org/10.3390/ catal11030365

Academic Editor: Vasile I. Parvulescu

Received: 8 February 2021

Accepted: 6 March 2021

Published: 10 March 2021

Publisher's Note: MDPI stays neutral with regard to jurisdictional claims in published maps and institutional affiliations.

Copyright: (c) 2021 by the authors. Licensee MDPI, Basel, Switzerland. This article is an open access article distributed under the terms and conditions of the Creative Commons Attribution (CC BY) license (https:/ / creativecommons.org/licenses/by/ $4.0 /)$.

\begin{abstract}
The presence of bromate in water sources generates environmental concern due to its toxicity for humans. Diverse technologies, like membranes, ion exchange, chemical reduction, etc., can be employed to treat bromate-polluted water but they produce waste that must be treated. An alternative to these technologies can be the catalytic reduction of bromate to bromide using hydrogen as a reducing agent. In this review, we analyze the research published about this catalytic technology. Specifically, we summarize and discuss about the state of knowledge related to (1) the different metals used as catalysts for the reaction; (2) the influence of the support on the catalytic activity; (3) the characterization of the catalysts; (4) the reaction mechanisms; and (5) the influence of the water composition in the catalytic activity and in the catalyst stability. Based on published papers, we analyze the strength and weaknesses of this technique and the possibilities of using this reaction for the treatment of bromate-polluted water as a sustainable process.
\end{abstract}

Keywords: bromate; catalytic hydrogenation; water pollution

\section{Introduction}

Environmental catalysis is a sustainable and valuable tool for the control of different pollutants. It has been successfully used for the removal of some air pollutants as $\mathrm{NO}_{\mathrm{x}}$ VOCs etc. [1-8]. Nevertheless, the use of catalysis for the control of water pollutants is more complicated because catalysts must be stable in order to avoid leaching to water and must be active at room temperature and atmospheric pressure in order to be economically viable. Besides that, polluted water could contain many other chemical species with diverse nature and characteristics that can affect the catalytic behavior. This complex composition could reduce or hinder the efficiency of the catalysts for the removal of specific water pollutants. Recently, several articles were published studying the use of catalytic hydrogenation for the control of some water pollutants like halogenated organic compounds, nitrosamines, nitrate, nitrite, or bromate [9-15].

Bromate oxyanion is highly soluble and stable in water [16]. It is considered to be a mutagenic agent and carcinogenic substance (group 2B-possibly carcinogenic for humans) [17]. For this reason, the European Union stablished a reference value of $0.01 \mathrm{mg} / \mathrm{L}$ of bromate in drinking water [18]. The same reference level was stablished in the US, Canada, and other developed countries.

Bromate is a non-natural water pollutant, mainly formed by the oxidation of bromide ions, usually present in water. This oxidation occurs during water treatments with ozone or when using chloride compounds. Specifically, ozonation is one of the most efficient and used techniques for water purification and wastewater treatment, but it is the main factor responsible for the presence of bromate in drinking water [19,20]. Diverse studies showed that the ozone dose, concentration of bromide, $\mathrm{pH}$, alkalinity, temperature, and the presence of ammonia are the most important parameters that influence the bromate formation during the water ozonation process [21,22]. Most of these parameters depend on the nature of the water and they cannot be fixed. Consequently, the preventive methods 
have a very limited efficiency for the control of this pollutant, and other strategies must be studied and developed $[21,23,24]$. Some alternatives for the preventive treatments could be chemical reduction [25], adsorption [26], ionic exchange [27], photochemistry [28], biological treatments [29], or separation through membranes [30].

Among all these methods, direct chemical reduction stands out as the most common and studied method [25,31-38]. Fe(0) is the most used reducing agent because its redox potential permits the oxidation of $\mathrm{Fe}(0)$ to $\mathrm{Fe}(\mathrm{II})$ or $\mathrm{Fe}(\mathrm{III})$, being bromate reduced to bromide.

$$
\begin{gathered}
\mathrm{BrO}_{3}^{-}+3 \mathrm{Fe}^{0}+6 \mathrm{H}^{+} \leftrightarrow \mathrm{Br}^{-}+3 \mathrm{Fe}^{2+}+3 \mathrm{H}_{2} \mathrm{O} \\
\mathrm{BrO}_{3}^{-}+2 \mathrm{Fe}^{0}+3 \mathrm{H}_{2} \mathrm{O} \rightarrow \mathrm{Br}^{-}+2 \mathrm{Fe}^{+3}+6 \mathrm{OH}^{-}
\end{gathered}
$$

Westerhoff and colleagues established that the selection of the iron source is critical in order to obtain good results [39]. Moreover, highly reactive micro-sized zero-valent iron immobilized in acrylic acid functionalized polypropylene fiber has been described as a successful material for the bromate removal. Using this material, $\mathrm{Fe}^{2+/ 3+}$ could remain in the carrier and not be released into solution [35]. Other authors suggested the use of $\mathrm{Fe}\left(\mathrm{SO}_{4}\right)$ for removing bromates (Equation (3)), according to its dual reductor-coagulant properties [32].

$$
\mathrm{BrO}_{3}^{-}+6 \mathrm{Fe}^{2+}+6 \mathrm{H}^{+} \leftrightarrow \mathrm{Br}^{-}+6 \mathrm{Fe}^{3+}+3 \mathrm{H}_{2} \mathrm{O}
$$

However, when using natural water, simultaneously to this reaction, other reactions occur that form different compounds giving turbidity to water and deactivating the iron sites [32]. Other zero-valent metals such as $\mathrm{Zn}$ or $\mathrm{Al}$ [36] were also investigated as active materials for bromate chemical reduction.

Diverse activated carbon materials have also shown some activity for bromate removal through adsorption. Nevertheless, the low bromate adsorption capacity and the low effectivity of the technique $[26,40]$ restrain the real use of this technique. Additionally, nanofiltration and osmosis membranes were evaluated. However, the most important drawback of these techniques is the cost related to the necessity of a pressure higher than atmospheric and to the maintenance of the system [30,41,42]. Other separation techniques like ion exchange membranes have a high efficiency, $[43,44]$. However, all these techniques generate byproducts or brine that must be treated and disposed, raising the price of the technique.

Bromate direct photo-dissociation was also proposed for the treatment of bromatepolluted water. Despite of the simplicity, a long-time of irradiation is necessary to achieve effective results, as well as the absence of other photo-reactive species, preventing its application in real water $[45,46]$. Other photochemical approaches were studied in order to achieve a suitable removal of bromates in water, most of them using photocatalytical processes with $\mathrm{TiO}_{2}$ [28,47-51]. Although the results obtained with these strategies were good enough, again, the applicability to real polluted waters presented different problems related to the needed irradiation time and area, to the possible interferences with other substances present in the treated water and to the energetic cost.

Biological removal of bromate was described by Hijen et al. [52] using denitrification bacteria in anaerobic conditions or by Ginkel and collaborators [29] with a mix of microorganisms that use bromate as electron acceptors. Nevertheless, all these biological treatments require long time periods to be effective.

Although all the above described methods are effective in different time scales, they produce byproducts that need to be removed, increasing the cost of the process and weakening the sustainability of the processes.

One possible alternative could be the catalytic reduction of bromate to bromide. This technique does not produce byproducts and the bromate removal rate is usually high. Dung et al. [53] showed that $\mathrm{RuO}_{2}$ supported on $\mathrm{TiO}_{2}$ catalyzes the bromate reduction, whilst water molecules were oxidized. The influence of $\mathrm{pH}$ in the reaction was also studied. An acidic $\mathrm{pH}$ was necessary to increase the reaction rate, but when $\mathrm{pH}$ was too low, $\mathrm{Br}_{2}$ 
instead of $\mathrm{Br}^{-}$was formed. Other authors also studied the use of $\mathrm{RuO}_{2}$ as a catalyst, but supported on activated carbon, obtaining interesting results [54,55].

Nevertheless, the results obtained with these catalysts were not good enough for commercial use. To improve the catalytic behavior, a reducing agent was added to the system, as it was done for the removal of other pollutants in water phase as nitrates $[56,57]$. In this way, the use of hydrogen as a reducing agent is the most suitable option, although other reducing agents such as alcohols [58] or sodium borohydride [59,60] were also evaluated. The advantage of using $\mathrm{H}_{2}$ compared to other agents is related to the nonmodification of the quality of the properties of the treated water. Thus, bromate can be reduced to bromide according to this reaction:

$$
\mathrm{BrO}_{3}^{-}+3 \mathrm{H}_{2} \leftrightarrow \mathrm{Br}^{-}+3 \mathrm{H}_{2} \mathrm{O}
$$

Chen et al. [61] first reported the use of this reaction for the treatment of bromatepolluted water using noble metal catalysts that activate hydrogen at room temperature and atmospheric pressure. They obtained promising results highlighting the potential of this catalytic reaction as an effective approach to eliminate bromate contamination in drinking water. After this pioneering work, different scientific studies were published employing diverse catalysts for this reaction. In this review, we analyze many of them in terms of (1) the different metals used as catalytic active species; (2) the influence of the support on the catalytic activity; (3) the most relevant characterization of the catalysts; (4) the mechanisms proposed for the reaction; and (5) the influence of the water composition in the catalytic behavior and the stability of the materials.

\section{Catalysts for the Bromate Hydrogenation}

\subsection{Influence of the Metallic Active Species}

The use of catalytic bromate hydrogenation for decontamination of polluted water will be economically viable only if the reaction is made at atmospheric pressure and room temperature. According to this demand, the catalyst must be very active under soft conditions activating the hydrogen molecules. For this reason, catalysts based on noble metals with hydrogenation properties are mainly used for this reaction.

In general, Pd-based catalysts are the most used as they are active for different hydrogenation reactions used for removing water pollutants [9]. Nevertheless, diverse metals were also explored. Chen et al. [61] studied the use of Pd and Pt supported on alumina (Figure $1 \mathrm{~b}$ ). Although both type of catalysts displayed significant and promising results, the Pd-based catalysts were the most active, probably due to the higher $\mathrm{H}_{2}$ dissociative adsorption capacity. On the contrary, Pt-catalysts were more active than the Pd catalysts when mesoporous SBA-15 was used as support, suggesting that other properties related to the support affect the catalytic behavior [62]. Other authors compared the catalytic removal of bromates using commercial catalysts based on activated carbon or alumina with different metals such as Pd, Pt, Ru, Rh, and Ir [63]. Results revealed different catalytic performances depending on the selected metal, metal content and, medium $\mathrm{pH}$. At neutral $\mathrm{pH}$, catalysts based on group IX (Rh and Ir) presented the best turn over frequency (TOF). However, when $\mathrm{pH}$ was decreased to 3.0, the best results were obtained using the catalysts based on the metals of the group X ( $\mathrm{Pd}$ and $\mathrm{Pt}$ ). Regarding to $\mathrm{Ru}$ (group VIII), this catalyst presented the worst activity in both $\mathrm{pH}$ conditions. Authors linked these results with the different nature of the immobilized metals, particularly with the hydrogenation properties and with the metal-bromate interaction. 

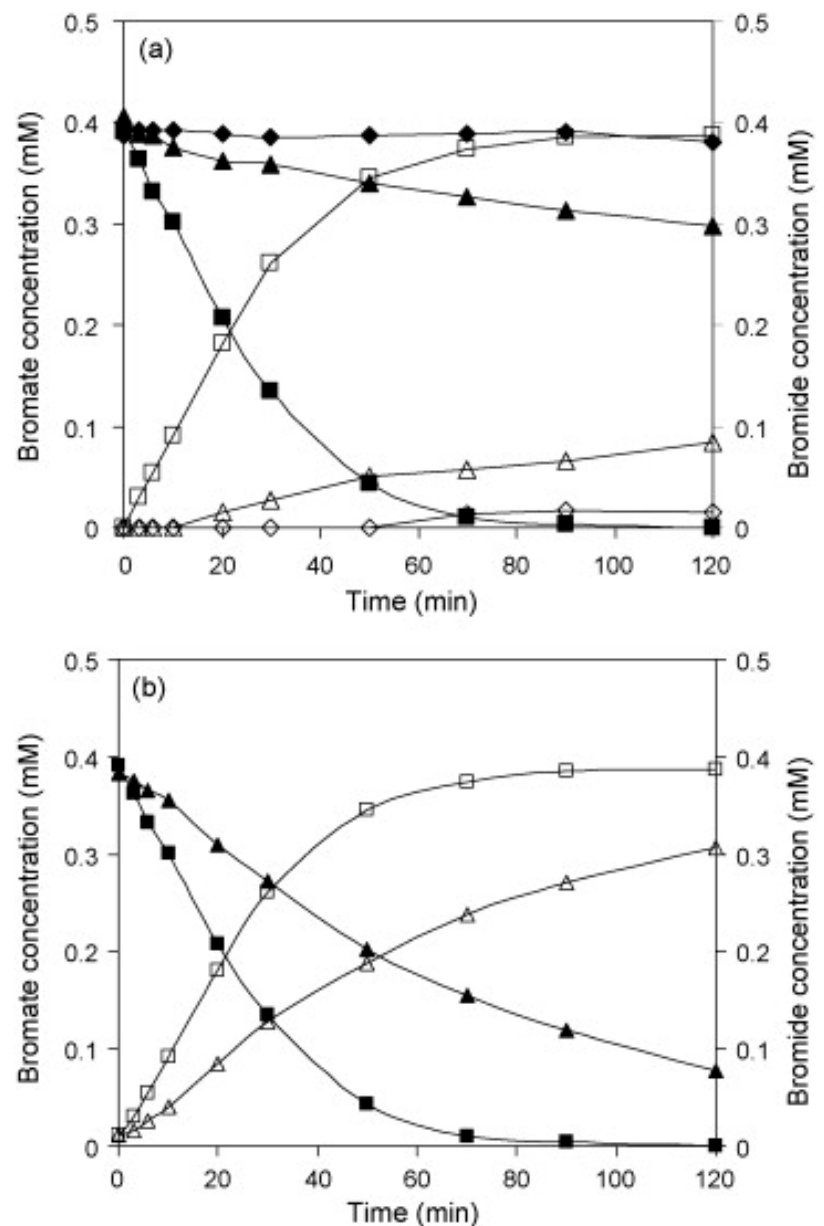

Figure 1. (a) Catalytic bromate reduction over $(\diamond, \diamond) \mathrm{Pd}(2.0) / \mathrm{SiO}_{2},(\boldsymbol{\square}, \square) \operatorname{Pd}(1.93) / \mathrm{Al}_{2} \mathrm{O}_{3}$, and $(\boldsymbol{\Lambda}, \Delta)$ $\mathrm{Pd}(2.0)$ /activated carbon catalysts and $(\mathbf{b})$ catalytic bromate reduction over $(\boldsymbol{\square}, \square) \mathrm{Pd}(1.93) / \mathrm{Al}_{2} \mathrm{O}_{3}$ and $(\boldsymbol{\Lambda}, \Delta) \mathrm{Pt}(2.0) / \mathrm{Al}_{2} \mathrm{O}_{3}$ catalysts at $\mathrm{pH} 5.6$ and $0.39 \mathrm{mM}$ as initial bromate concentration. Filled symbols denote bromate concentration and open symbols denote bromide concentration. Reprinted from [61], Copyright (2010), with permission from Elsevier.

On the other hand, Restivo et al. proposed different conclusions [64] studying catalysts based on activated carbon supporting $1 \mathrm{wt}$.\% of different metals $(\mathrm{Pt}, \mathrm{Pd}, \mathrm{Cu}, \mathrm{Sn}, \mathrm{Rh}, \mathrm{Ru}$, $\mathrm{Ni}$, Ir, Fe, or $\mathrm{Zn}$ ). Their results showed a $90 \%$ conversion using non-noble metals after $120 \mathrm{~min}$ and almost total conversion using noble metals (see Figure 2). In this study, the highest activity referred to the available metallic surface area was obtained with Pt catalysts, although the Pd catalyst was the most efficient in terms of bromate conversion. The catalytic outcomes were correlated with the dissociative chemisorption energy of hydrogen over the diverse metals. This analysis demonstrated that the most active catalysts were those presenting a medium-strength bond with hydrogen. On the other hand, it is interesting to point out that in this paper, non-noble metals are also proposed as active catalysts for this reaction. This type of catalyst are less active than noble metals, but they are a lower cost option, and if further research proves the activity and stability of these materials in natural water, they could be an interesting alternative to catalysts based on noble metals. 


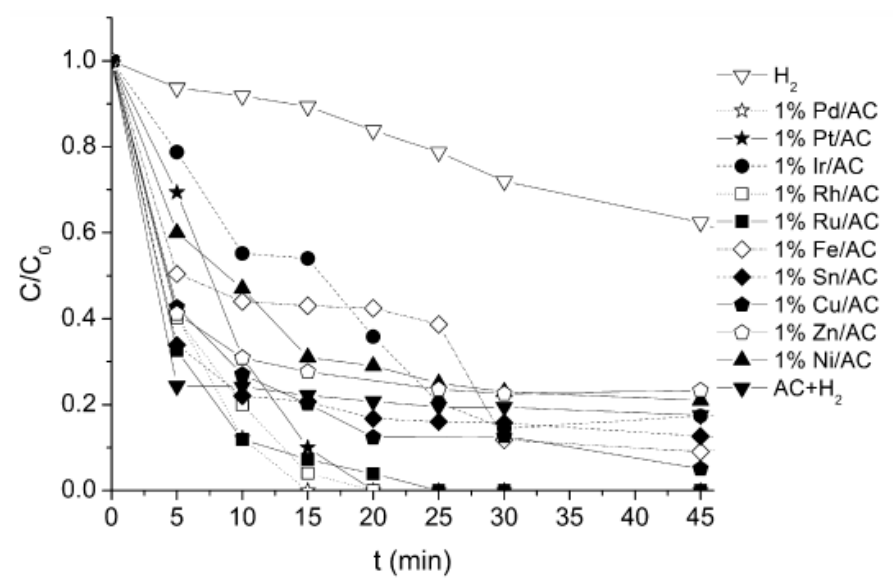

Figure 2. Dimensionless concentration of bromate during catalytic reduction experiments using hydrogen in the presence of monometallic catalysts supported on activated carbon (AC). Reprinted from [64], Copyright (2015), with permission from Elsevier.

The use of bimetallic catalysts for this reaction, combining a noble and a non-noble metal was also studied, as these types of catalysts were previously used for the catalytic hydrogenation of other inorganic water-pollutants, such as nitrates $[65,66]$. The obtained results were reported in different scientific articles [67-69] and suggested that the presence of a second metal hindered the hydrogenative activity of the noble metal. However, the Pd-Cu bimetallic catalysts slightly improved the catalytic activity (see Figure 3), although this enhancement was not enough to justify the use of both metals. However, Palomares et al. [70] evidenced that a bimetallic Pd-Sn catalyst can be used for the simultaneous removal of bromates and nitrates thus adding interest to the use of these bimetallic catalysts (Figure 4).

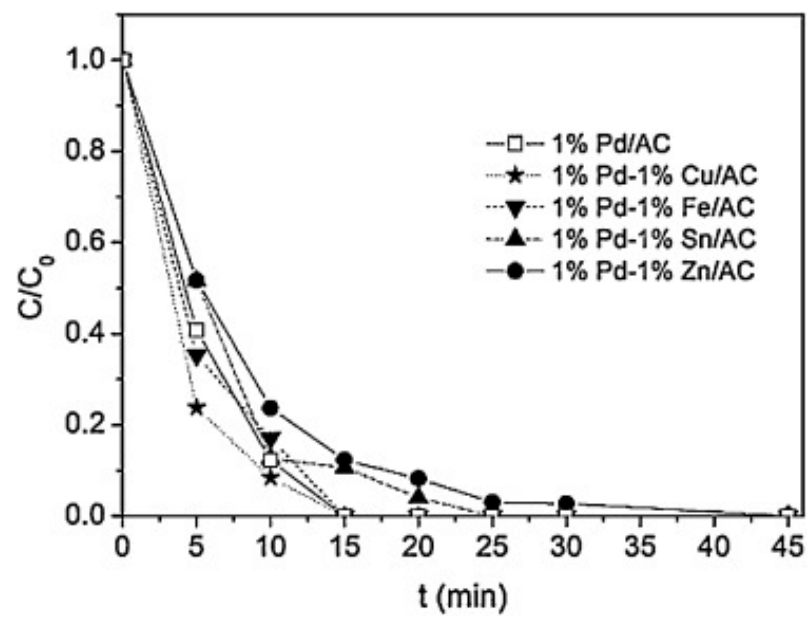

Figure 3. Evolution of the dimensionless concentration of bromate for reduction experiments using $\mathrm{H}_{2}$ and bimetallic palladium catalysts supported on activated carbon (AC). Reprinted from [67], Copyright (2015), with permission from Elsevier.

Other authors such as Chen and collaborators [71] also studied the use of non-noble metals as primary catalysts, specifically, they analyzed the activity of $\mathrm{CoS}_{2}$ hollow spheres. This Co-based catalyst displayed good results for the removal of bromates in both artificialand tap-polluted waters (Figure 5). 


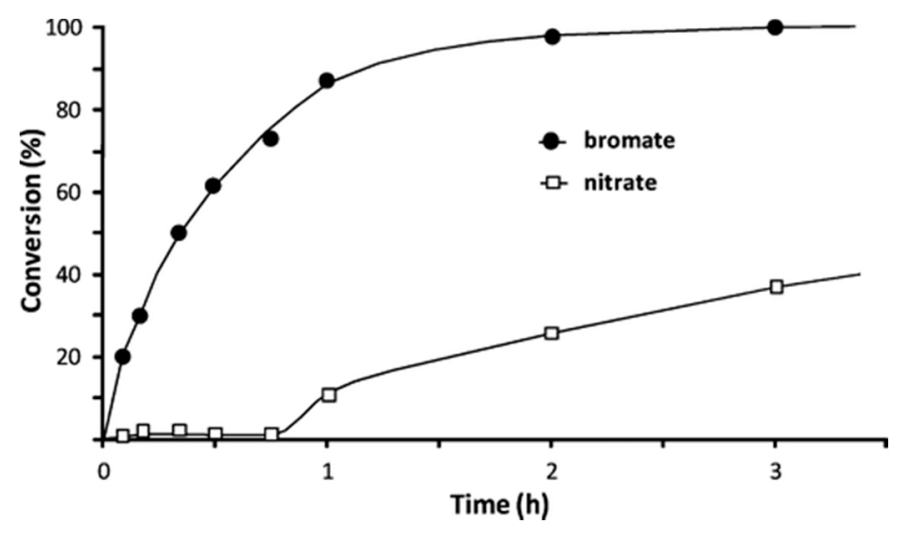

Figure 4. Simultaneous removal of bromate and nitrate ions over the $(\mathrm{Pd} / \mathrm{Sn}-0.3 / 0.15) / 5 \%$ carbon nanofibers grown on sintered metal fibers catalyst $\left(\left[\mathrm{BrO}_{3}{ }^{-}\right]=50 \mathrm{mg} / \mathrm{L} ;\left[\mathrm{NO}_{3}{ }^{-}\right]=100 \mathrm{mg} / \mathrm{L}\right.$; mcat $=2.5 \mathrm{~g} ; \mathrm{T}=25^{\circ} \mathrm{C}$ ). Reprinted with permission from [70], Copyright (2013) American Chemical Society.

On the other hand, the analysis of the different publications showed that significant differences in reaction rates arose when the same catalyst was prepared by different methods. For instance, Gao and collaborators evaluated the activity of catalysts based on $\mathrm{Pd}$ supported on $\mathrm{Al}_{2} \mathrm{O}_{3}$ prepared by two methods, wet impregnation and spraying [72]. The bromate removal rate was higher when the spraying method was employed. These results were related to the higher Pd dispersion obtained with the sprayed catalyst. It was shown that the catalyst preparation method influenced in the physicochemical properties of the catalysts and then in the catalytic performance.

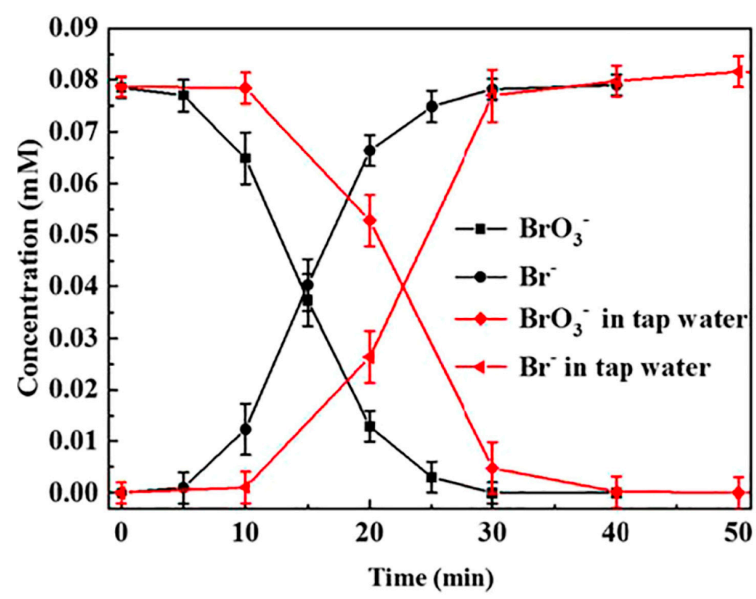

Figure 5. The bromate/bromide concentration changes in treated tap water and distilled water with initial bromate concentration of $0.078 \mathrm{mM}$ over $\mathrm{CoS}_{2}$ hollow spheres catalyst. Reprinted from [71], Copyright (2020), with permission from Elsevier.

The reviewed literature shows discrepancies about which is the optimum crystallite metal size to achieve the best activity. The studies dealing with this point were mainly made with Pd-based catalysts. Some authors concluded that catalysts with large crystallite size and lower metallic dispersion were more active because the chemisorption and dissociation of $\mathrm{H}_{2}$ was enhanced, [61,73-75]. On the contrary, other authors [72,76] indicated that better results were obtained when $\mathrm{Pd}$ nanoparticles were more disperse, this is with a lower particle size, because more available active sites were present. Nonetheless this discussion is quite complex because of the different techniques used to measure $\mathrm{Pd}$ dispersion and crystallite size (electronic microscopy, molecule adsorption, XRD), as well as the different ways to calculate TOF. In general, when the TOF was referred to real Pd exposed, a higher TOF was obtained with low metal dispersed catalysts. The different discussions proved that 
the activity of the metal sites was related to the metallic crystallite size, being the activity of the large crystals higher than that of small metallic crystals. It is worth mentioning that high crystallite size results in low metal dispersion and then in a large portion of non-accessible metal, for that reason an equilibrium between very active high crystallite size and good metal dispersion is necessary in order to design a commercial catalyst [77].

The results and conclusions of these previous studies highlighted that the chemical nature of the metals, the metal loading, the presence of a second metal, and the method used to incorporate the metallic species influenced in the catalytic performance. The analysis of the different papers clearly indicated that noble metals are necessary for the activation of hydrogen at room temperature, with $\mathrm{Pd}$ (and $\mathrm{Pt}$ ) as the most active, although some activity can be obtained with non-noble metals. This analysis also indicated that the synthesis method must be designed to obtain well dispersed large metal crystallites, i.e., avoiding the formation of metal aggregates.

\subsection{Influence of the Support}

Another important factor controlling the activity of the catalysts in this reaction is the support. It can influence on the density, size, and morphology of metal active sites, and therefore, on the activity of the catalyst. Moreover, the properties of the support, such as the superficial charge, superficial area, or porosity, highly influence the catalytic performance. The main supports used in the scientific literature for this reaction were $\mathrm{Al}_{2} \mathrm{O}_{3}$ and activated carbon $[61,63,64,67,72]$, although other supports were also studied, such as carbon nanotubes [78,79], mesoporous materials [74,76,80], zeolites [68,69], activated carbon fibers [70,73,81], $\mathrm{SiO}_{2}$ [82], $\mathrm{TiO}_{2}$ [78], $\mathrm{Fe}_{3} \mathrm{O}_{4}$ [75], core-shell structured magnetite [83], dual supports such as SBA-15 with $\mathrm{CeO}_{2}$ [76], SBA-15 functionalized with amino groups [84], or even monoliths coated with carbon nanofibers $[73,85]$.

Chen et al. [61] defined $\mathrm{Al}_{2} \mathrm{O}_{3}$ as the most suitable support compared to $\mathrm{SiO}_{2}$ and activated carbon (Figure $1 \mathrm{a}$ ), due to the higher isoelectronic point of $\mathrm{Al}_{2} \mathrm{O}_{3}$ that results on a positively charged surface. On the other side, Coronado et al. described that better results were obtained when using $\mathrm{TiO}_{2}$ as support than when using carbon nanotubes, even presenting the last a lower porosity and surface area. This was explained by the good interaction of bromate- $\mathrm{TiO}_{2}$ and by the strong metal support interaction (SMSI) that transfers electrons to the metallic particles enhancing the reduction process [78]. Other authors made emphasis of the importance of the support mesoporosity that minimizes diffusional problems [80] and in the support functionalization to improve the metal dispersion [76,86] or to obtain a proper surface charge $[74,84]$. Recently, new studies described the use of catalysts with magnetic properties, placing value on their easy separation [83].

In general, most of the reviewed articles presented diverse catalytic performances using catalysts with similar metallic loading, but supported on different materials. These differences are mainly related to three properties of the support, i.e., the surface charge (related with the potential zeta or point of zero charge (PZC)), the porous structure, and the interaction of the metal with the support [77]. Most of the studies concluded that a positive surface charge is necessary for a proper adsorption of the bromate reactant on the catalyst surface, in this sense, a support with a high PZC is the most convenient. It is also convenient to use supports prone to the formation of large metallic sites, because large crystals favor $\mathrm{H}_{2}$ adsorption and activation, but that simultaneously prevent the formation of aggregations. On the other hand, better results were obtained with mesoporous supports, with high external surface area, avoiding microporous supports that hinder the reactants adsorption. Overall, the analyzed results clearly show that the interaction between bromate ions and the support surface has a greater influence in the catalyst activity than other physico-chemical properties of the support as the surface area or the metal dispersion [61,74].

A summary of the catalytic results discussed above and published in recent years appears in Table 1 (discontinuous reaction systems) and Table 2 (continuous reaction systems). In the tables are indicated the synthesis method used for the preparation of the 
catalysts, the catalytic conditions, and the activity of the catalysts expressed as conversion at $5 \mathrm{~min}$ and efficiency defined as conversion at $5 \mathrm{~min}$ per gram of metal.

\section{Catalyst Characterization and Active Sites}

As previously stated, the catalytic hydrogenation of bromate at room temperature and atmospheric pressure was mainly studied with catalysts based on palladium and the discussion made in this point was focused on those catalysts. They were prepared using different supports, with different Pd precursors, or even using diverse synthesis methods. The different physicochemical properties of the catalysts result in a different activity therefore it is necessary to characterize the materials.

The catalysts were characterized by different techniques as X-ray absorption spectroscopy (XAS); $\mathrm{X}$-ray diffraction (XRD); $\mathrm{N}_{2}$ adsorption/desorption; infrared spectroscopy (FTIR); CO chemisorption; diverse electronic microscopy techniques (SEM, TEM, and EDX); $\mathrm{X}$-ray photoelectron spectroscopy (XPS); optical emission spectroscopy (ICP-OES); and thermo-programmed reduction experiments (TPR) among others.

Most of the papers focused the discussion in the size of the metal crystallites and in the PZC of the support. Chen et al. [61] employed TEM to determine particle size of metallic nanoparticles and measured small $\mathrm{Pd}$ nanoparticles $(0-5 \mathrm{~nm})$ for catalysts containing 0.5 wt.\% Pd supported on $\mathrm{Al}_{2} \mathrm{O}_{3}$, whereas increasing Pd loading up to $5 \mathrm{wt} . \%$ resulted in particles of 10-12 nm. The different metal particle size gave different metallic dispersion, i.e., $45 \%$ for the catalyst with smaller size and $9 \%$ for those with larger crystallite size. Other researchers [72] reported Pd metallic dispersion from 13 to $22 \%$ and average $\mathrm{Pd}$ particle size between 5 and $8 \mathrm{~nm}$ for catalysts containing $0.8-1 \%$ of $\mathrm{Pd}$ supported on $\mathrm{Al}_{2} \mathrm{O}_{3}$. Restivo et al. [67] tested bimetallic catalysts supported on activated carbon presenting nanoparticles between 3-7 nm, although a few larger particles were also observed. On the contrary, by using monometallic catalysts [64] the palladium nanoparticles were smaller $(2.9 \mathrm{~nm})$, with a Pd dispersion close to $40 \%$. These authors claimed [79] that the Pd dispersion and therefore, the nanoparticle size depend on the support, obtaining smaller $\mathrm{Pd}$ particles with an activated carbon support $(2.9 \mathrm{~nm})$ than with $\mathrm{TiO}_{2}$ support $(12 \mathrm{~nm})$. Recently, it was shown that the metallic precursor used for the preparation of the catalyst also influences the final size of the metallic crystallite [77] and the metal distribution on the support surface (see Figure 6).

The synthetic method also modifies the Pd nanoparticles' size. Sun et al. [74] described different metal particle size when Pd was incorporated by electrostatic adsorption or conventional impregnation. Likewise, Chen et al. [76] revealed different Pd dispersion depending on the method used for the metal deposition. Coronado et al. [78] obtained diverse Pd nanoparticles from 6 to $11 \mathrm{~nm}$ depending on the catalyst preparation method, the support employed, the support functionalization previous to the Pd incorporation, and the activation temperature. In general, the increase of the activation temperature and/or the Pd loading drives to larger metallic particle sizes, and then to lower metallic dispersion.

Other techniques like XPS were used in different investigations. The XPS study carried out by Gao and collaborators demonstrated that the Pd content on the catalyst surface mainly depends on the method used for the catalyst preparation [72]. In general, most of the active catalysts exhibited $\mathrm{Pd}(0)$ as the main Pd-specie [77], although some $\mathrm{Pd}^{\mathrm{n}+}$ species were also formed $[78,81]$. The oxidated species can be related to the formation of uncoordinated sites due to the size and morphology of the nanoparticles over the support and their presence was representative of strong metal-support interactions [74].

TPR experiments determined the easy reduction of Pd species and evidenced that $\operatorname{Pd}(0)$ is the main specie formed after catalyst activation [61]. Furthermore, some authors showed the formation of Pd-hydride ( $\beta-\mathrm{PdH})$ [87], the presence of these species was more evident in catalysts with higher Pd content. Chen et al. exposed that a high content of metallic $\mathrm{Pd}$ on alumina surface makes easy the activation and storage of $\mathrm{H}_{2}$ molecules at room temperature and hence facilitates the reduction reaction under mild reaction conditions [61] due to the formation of the palladium $\beta$-hydrides. 

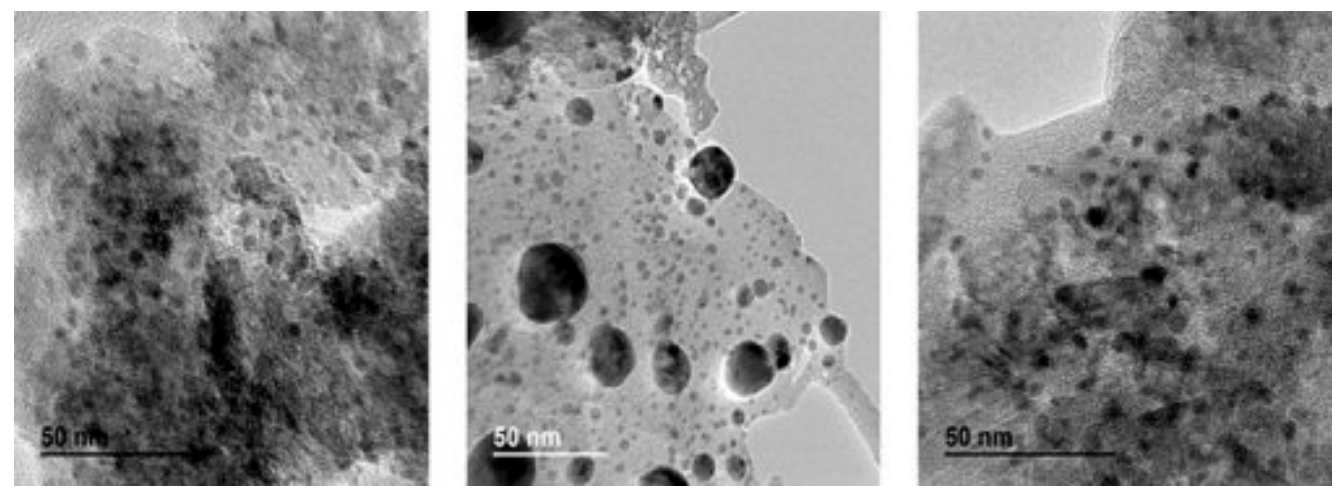

Figure 6. TEM images of $7 \% \mathrm{Pd} / \mathrm{Al}_{2} \mathrm{O}_{3}$ catalysts prepared with different precursors: (right) acetate, (middle) nitrate, (left) chloride. Reprinted from [77], Copyright (2021), with permission from John Wiley and Sons.

The reviewed literature did not evidence significant modifications in the surface area and textural properties after the incorporation of Pd or other metals $[67,88]$, depending these characteristics almost exclusively on the support. Similarly, XRD studies did not exhibit significant modification of the different supports after the incorporation of the metallic nanoparticles [69]. The patterns of the catalysts only showed new peaks related to the reduced metal after activation. These peaks were easily observed in catalysts with high metallic content [77] and low metal dispersion.

Finally, advanced characterization techniques were used to characterize the $\mathrm{Pd}$ catalysts used in this reaction. Specifically, in situ X-ray Absorption Spectroscopy (XAS) experiments $[73,88]$ were carried out to track the activation process as well as the possible evolution of the Pd species during the reaction. Those experiments showed that, independently of the amount of $\mathrm{Pd}$ or the support, the activation process produced the reduction of $\mathrm{Pd}^{2+}$ to $\mathrm{Pd}(0)$ during the thermal treatment with hydrogen. After cooling down the catalyst to room temperature, the formation of palladium $\beta$-hydride was detected. During the reaction, $\operatorname{Pd}(0)$ species stayed unaltered, demonstrating that catalysts are not deactivated along the reaction, showing their stability $[73,88]$.

The analysis of the literature related with the characterization of the Pd catalysts used for the bromate reaction shows that the main differences on the catalyst activity depend on the metal crystallite size. This variable can be related with the metal loading, the synthetic procedure, the metal precursor, the activation temperature, and the support. These principal factors determine the catalytic behavior as they are directly related with the metal particle size.

Table 1. Summary of the catalysts used for the bromate hydrogenation reaction at room temperature $\left(22-27^{\circ} \mathrm{C}\right)$ and atmospheric pressure using discontinuous reactors.

\begin{tabular}{|c|c|c|c|c|c|c|}
\hline Support & Metal \& Loading & $\begin{array}{l}\text { Incorporation } \\
\text { Method }\end{array}$ & $\begin{array}{c}\mathrm{BrO}_{3}^{-} \text {Initial } \\
\left(\mathrm{mmol}^{-} \mathrm{L}^{-1}\right)\end{array}$ & $\begin{array}{l}\text { Conversion } \\
\text { at } 5 \text { min } \\
(\%)\end{array}$ & $\begin{array}{c}\text { Efficiency at } 5 \text { min } \\
\left(\mathrm{mmol} \mathrm{BrO}_{3}^{-}\right. \\
\text {Conversion } \mathrm{g} \mathrm{metal}^{-1} \text { ) }\end{array}$ & Reference \\
\hline $\mathrm{TiO}_{2}$ & $\operatorname{Pd}(3.6 \%)$ & $\begin{array}{l}\text { Micro- } \\
\text { emulsion }\end{array}$ & 0.078 & 96 & 17.74 & [78] \\
\hline SBA-15 doped with $\mathrm{CeO}_{2}$ & $\mathrm{Pd}(0.1 \%)$ & $\begin{array}{l}\text { electrostatic } \\
\text { adsorption }\end{array}$ & 0.6 & 30 & 760.14 & [74] \\
\hline SBA-15 & $\begin{array}{l}\mathrm{Pd}(3.9 \%) \\
\mathrm{Pt}(3.9 \%)\end{array}$ & $\begin{array}{l}\text { adsorption } \\
\text { adsorption }\end{array}$ & $\begin{array}{l}0.78 \\
0.78 \\
\end{array}$ & $\begin{array}{l}45 \\
65\end{array}$ & $\begin{array}{l}30.07 \\
43.22 \\
\end{array}$ & [62] \\
\hline SBA-15 doped with - $\mathrm{NH}_{2}$ & $\mathrm{Pt}(4.0 \%)$ & adsorption & 0,78 & 63 & 47.89 & [84] \\
\hline $\mathrm{Al}_{2} \mathrm{O}_{3}$ & $\mathrm{Pd}(0.9 \%)$ & spraying & 0.4 & 47 & 427.28 & [72] \\
\hline
\end{tabular}


Table 1. Cont.

\begin{tabular}{|c|c|c|c|c|c|c|}
\hline Support & Metal \& Loading & $\begin{array}{l}\text { Incorporation } \\
\text { Method }\end{array}$ & $\begin{array}{l}\mathrm{BrO}_{3}-\text { Initial } \\
\left(\mathrm{mmol} \cdot \mathrm{L}^{-1}\right)\end{array}$ & $\begin{array}{l}\text { Conversion } \\
\text { at } 5 \text { min } \\
(\%)\end{array}$ & 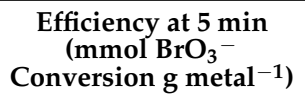 & Reference \\
\hline \multirow{5}{*}{ Activated Carbon } & $\mathrm{Pd}(5.0 \%)$ & commercial & 1 & 15 & 3.19 & \multirow{9}{*}[63]{} \\
\hline & $\operatorname{Rh}(5.0 \%)$ & commercial & 1 & 100 & 21.28 & \\
\hline & $\mathrm{Ru}(5.0 \%)$ & commercial & 1 & 2 & 0.43 & \\
\hline & $\operatorname{Pt}(5.0 \%)$ & commercial & 1 & 5 & 1.06 & \\
\hline & $\operatorname{Ir}(1.0 \%)$ & commercial & 1 & 10 & 10.64 & \\
\hline \multirow{4}{*}{$\mathrm{Al}_{2} \mathrm{O}_{3}$} & $\operatorname{Pd}(5.0 \%)$ & commercial & 1 & 10 & 2.13 & \\
\hline & $\operatorname{Rh}(5.0 \%)$ & commercial & 1 & 50 & 10.64 & \\
\hline & $\mathrm{Ru}(5.0 \%)$ & commercial & 1 & 7 & 1.49 & \\
\hline & $\operatorname{Pt}(5.0 \%)$ & commercial & 1 & 9 & 1.92 & \\
\hline $\mathrm{Al}_{2} \mathrm{O}_{3}$ & $\mathrm{Pd}(1.0 \%)$ & impregnation & 0.39 & 12 & 56 & \multirow{3}{*}[77]{} \\
\hline Activated Carbon & $\mathrm{Pd}(1.0 \%)$ & impregnation & 0.39 & 7 & 3.23 & \\
\hline Hydrotalcite (Mg/Al) & $\operatorname{Pd}(1.0 \%)$ & impregnation & 0.39 & 2 & 1.04 & \\
\hline \multirow{3}{*}{$\mathrm{Al}_{2} \mathrm{O}_{3}$} & $\mathrm{Pd}(2.0 \%)$ & impregnation & 0.4 & 18 & 73.84 & \multirow{5}{*}[61]{} \\
\hline & $\mathrm{Pd}(5.0 \%)$ & impregnation & 0.4 & 33 & 53.33 & \\
\hline & $\mathrm{Pt}(2.0 \%)$ & impregnation & 0.4 & 10 & 40 & \\
\hline $\mathrm{SiO}_{2}$ & $\operatorname{Pd}(2.0 \%)$ & impregnation & 0.4 & 3 & 12 & \\
\hline Activated Carbon & $\mathrm{Pd}(2.0 \%)$ & impregnation & 0.4 & 6 & 24 & \\
\hline $\begin{array}{c}\text { Activated carbon fibers } \\
\text { coating sintered metal } \\
\text { fibers (CNF/SMFs) }\end{array}$ & $\mathrm{Pd}(0.3 \%)$ & impregnation & 0.39 & 60 & 49.66 & {$[70,81]$} \\
\hline $\begin{array}{c}\text { Activated carbon fibers } \\
\text { coating cordierite } \\
\text { monoliths }\end{array}$ & $\mathrm{Pd}(0.5 \%)$ & adsorption & 0.39 & 35 & 57.47 & [85] \\
\hline \multirow{13}{*}{ Activated carbon } & $\operatorname{Pt}(1.0 \%)$ & impregnation & 0.078 & 30 & 1.06 & \multirow{5}{*}[64]{} \\
\hline & $\operatorname{Pd}(1.0 \%)$ & impregnation & 0.078 & 60 & 2.13 & \\
\hline & Sn $(1.0 \%)$ & impregnation & 0.078 & 69 & 3.19 & \\
\hline & $\mathrm{Rh}(1.0 \%)$ & impregnation & 0.078 & 50 & 2.13 & \\
\hline & $\mathrm{Ru}(1.0 \%)$ & impregnation & 0.078 & 67 & 3.19 & \\
\hline & $\begin{array}{c}\mathrm{Pd} / \mathrm{Cu} \\
(1.0 / 1.0 \%)\end{array}$ & impregnation & 0.078 & 78 & 3.19 & \multirow{8}{*}[67]{} \\
\hline & $\begin{array}{c}\mathrm{Pd} / \mathrm{Fe} \\
(1.0 / 1.0 \%)\end{array}$ & impregnation & 0.078 & 65 & 3.19 & \\
\hline & $\begin{array}{c}\mathrm{Pd} / \mathrm{Sn} \\
(1.0 / 1.0 \%)\end{array}$ & impregnation & 0.078 & 50 & 2.13 & \\
\hline & $\begin{array}{c}\mathrm{Pd} / \mathrm{Zn} \\
(1.0 / 1.0 \%)\end{array}$ & impregnation & 0.078 & 50 & 2.13 & \\
\hline & $\mathrm{Cu}(1.0 \%)$ & impregnation & 0.078 & 57 & 2.13 & \\
\hline & $\begin{array}{c}\mathrm{Ir} / \mathrm{Cu} \\
(1.0 / 1.0 \%)\end{array}$ & impregnation & 0.078 & 50 & 2.13 & \\
\hline & $\begin{array}{c}\mathrm{Pt} / \mathrm{Cu} \\
(1.0 / 1.0 \%)\end{array}$ & impregnation & 0.078 & 65 & 3.19 & \\
\hline & $\begin{array}{c}\mathrm{Ru} / \mathrm{Cu} \\
(1.0 / 1.0 \%)\end{array}$ & impregnation & 0.078 & 48 & 2.13 & \\
\hline \multirow{4}{*}{$\mathrm{TiO}_{2}$} & $\mathrm{Ru}(1.0 \%)$ & impregnation & 0.078 & 53 & 16.50 & \multirow{8}{*}{ [79] } \\
\hline & $\operatorname{Rh}(1.0 \%)$ & impregnation & 0.078 & 99 & 30.80 & \\
\hline & $\mathrm{Pd}(1.0 \%)$ & impregnation & 0.078 & 100 & 31.22 & \\
\hline & $\mathrm{Pt}(1.0 \%)$ & impregnation & 0.078 & 100 & 31.22 & \\
\hline \multirow{4}{*}{$\begin{array}{l}\text { Carbon nanotube } \\
\text { (MWCNT) }\end{array}$} & $\mathrm{Ru}(1.0 \%)$ & impregnation & 0.078 & 40 & 12.48 & \\
\hline & $\operatorname{Rh}(1.0 \%)$ & impregnation & 0.078 & 52 & 16.22 & \\
\hline & $\mathrm{Pd}(1.0 \%)$ & impregnation & 0.078 & 55 & 16.85 & \\
\hline & $\operatorname{Pt}(1.0 \%)$ & impregnation & 0.078 & 58 & 18.10 & \\
\hline $\begin{array}{l}\text { Activated carbon fibers } \\
\text { (ACF) }\end{array}$ & $\operatorname{Pd}(1.0 \%)$ & impregnation & 0.39 & 15 & 9.32 & [73] \\
\hline $\begin{array}{l}\text { Carbon nanofibers over } \\
\text { carbon felt } \\
(\mathrm{CNF} / \mathrm{CF})\end{array}$ & $\operatorname{Pd}(0.3 \%)$ & impregnation & 0.39 & 30 & 46.80 & \multirow{2}{*}{ [15] } \\
\hline $\begin{array}{c}\text { Carbon nanofibers over } \\
\text { metal fibers } \\
\text { (CNF/SMF) }\end{array}$ & $\mathrm{Pd}(0.3 \%)$ & impregnation & 0.39 & 12 & 18.76 & \\
\hline
\end{tabular}


Table 1. Cont.

\begin{tabular}{|c|c|c|c|c|c|c|}
\hline Support & Metal \& Loading & $\begin{array}{l}\text { Incorporation } \\
\text { Method }\end{array}$ & $\begin{array}{l}\mathrm{BrO}_{3}-\text { Initial } \\
\left(\mathrm{mmol} \cdot \mathrm{L}^{-1}\right)\end{array}$ & $\begin{array}{l}\text { Conversion } \\
\text { at } 5 \text { min } \\
(\%)\end{array}$ & $\begin{array}{c}\text { Efficiency at } 5 \mathrm{~min} \\
\left(\text { mmol } \mathrm{BrO}_{3}^{-}\right. \\
\left.\text {Conversion } \mathrm{g} \mathrm{metal}^{-1}\right)\end{array}$ & Reference \\
\hline \multirow{8}{*}{$\begin{array}{c}\text { Zeolite } \\
\text { (FAU) }\end{array}$} & $\operatorname{Pd}(1.0 \%)$ & Ion-exchange & 0.078 & 18 & 3.47 & \multirow{8}{*}{ [68] } \\
\hline & $\mathrm{Cu}(0.6 \%)$ & Ion-exchange & 0.078 & 10 & 3.55 & \\
\hline & $\operatorname{Rh}(0.2 \%)$ & Ion-exchange & 0.078 & 5 & 7.60 & \\
\hline & Th $(0.2 \%)$ & Ion-exchange & 0.078 & 5 & 6.26 & \\
\hline & $\begin{array}{c}\mathrm{Pd} / \mathrm{Cu} \\
(1.6 / 1.0 \%)\end{array}$ & Ion-exchange & 0.078 & 75 & 7.98 & \\
\hline & $\begin{array}{c}\mathrm{Cu} / \mathrm{Pd} \\
(0.7 / 1.8 \%)\end{array}$ & Ion-exchange & 0.078 & 85 & 7.69 & \\
\hline & $\begin{array}{c}\mathrm{Rh} / \mathrm{Cu} \\
(0.1 / 0.6 \%)\end{array}$ & Ion-exchange & 0.078 & 7 & - & \\
\hline & $\begin{array}{l}\text { Th/Cu } \\
(0.1 / 2.3 \%)\end{array}$ & Ion-exchange & 0.078 & 15 & - & \\
\hline \multirow{8}{*}{$\begin{array}{l}\text { Zeolite } \\
\text { (ZSM-5) }\end{array}$} & \multirow{8}{*}{$\begin{array}{c}\mathrm{Pd}(1.5 \%) \\
\mathrm{Cu}(0.9 \%) \\
\mathrm{Pd} / \mathrm{Cu} \\
(1.4 / 1.0 \%) \\
\mathrm{Cu} / \mathrm{Pd} \\
(0.6 / 1.9 \%) \\
\mathrm{Th}(0.4 \%) \\
\mathrm{Rh}(0.5 \%) \\
\mathrm{Th} / \mathrm{Cu} \\
(0.4 / 1.3 \%) \\
\mathrm{Rh} / \mathrm{Cu} \\
(0.4 / 1.6 \%)\end{array}$} & Ion-exchange & 0.078 & 20 & 3.19 & \multirow{8}{*}{ [69] } \\
\hline & & Ion-exchange & 0.078 & 12 & - & \\
\hline & & Ion-exchange & 0.078 & 80 & 9.88 & \\
\hline & & Ion-exchange & 0.078 & 88 & 7.84 & \\
\hline & & Ion-exchange & 0.078 & 5 & 2.66 & \\
\hline & & Ion-exchange & 0.078 & 15 & 4.73 & \\
\hline & & Ion-exchange & 0.078 & 85 & - & \\
\hline & & Ion-exchange & 0.078 & 15 & - & \\
\hline \multirow{2}{*}{$\begin{array}{l}\text { MCM-41 doped with } \\
\text { amino } \\
\text { groups }\end{array}$} & \multirow[b]{2}{*}{$\mathrm{Pd}(2.0 \%)$} & impregnation & 0.78 & 5 & 41.50 & \multirow[b]{2}{*}{ [76] } \\
\hline & & $\begin{array}{l}\text { Deposition- } \\
\text { precipitation }\end{array}$ & 0.78 & 12.5 & 103.76 & \\
\hline Mesoporous carbon nitride & $\mathrm{Pd}(2.2 \%)$ & impregnation & 0.78 & 12.5 & 157.21 & \multirow{3}{*}{ [80] } \\
\hline $\begin{array}{l}\text { Mesoporous carbon } \\
\text { CMK-3 }\end{array}$ & $\mathrm{Pd}(2.1 \%)$ & impregnation & 0.78 & 5 & 66.19 & \\
\hline Activated carbon & $\mathrm{Pd}(2.0 \%)$ & impregnation & 0.78 & 3 & 41.30 & \\
\hline $\mathrm{Fe}_{3} \mathrm{O}_{4}$ paramagnetic & $\mathrm{Pd}(1.0 \%)$ & $\begin{array}{l}\text { Adsorption- } \\
\text { impregnation }\end{array}$ & 0.39 & 35 & 68.43 & [75] \\
\hline $\mathrm{Fe}_{3} \mathrm{O}_{4}$ paramagnetic & $\mathrm{Pd}(3.5 \%)$ & $\begin{array}{l}\text { Adsorption- } \\
\text { sonication }\end{array}$ & 0.4 & 27 & 61.89 & [83] \\
\hline $\begin{array}{c}\mathrm{SiO}_{2} \\
\text { "core-shell" }\end{array}$ & $\mathrm{Pd}(3.0 \%)$ & impregnation & 0.1 & 33 & 14.54 & \multirow{3}{*}{ [82] } \\
\hline $\mathrm{SiO}_{2}$ & $\mathrm{Pd}(3.0 \%)$ & impregnation & 0.1 & 8 & 10.64 & \\
\hline nanoparticles & $\mathrm{Pd}(3.0 \%)$ & & 0.1 & 15 & 20.22 & \\
\hline $\begin{array}{c}\mathrm{CoS}_{2} \\
\text { hollow spheres }\end{array}$ & Co & $\begin{array}{l}\text { Hydrothermal } \\
\text { process }\end{array}$ & 0.39 & 12 & - & [71] \\
\hline
\end{tabular}

Table 2. Summary of the catalysts used for the bromate hydrogenation reaction at room temperature $\left(22-27^{\circ} \mathrm{C}\right)$ and atmospheric pressure using continuous reactors.

\begin{tabular}{|c|c|c|c|c|c|c|}
\hline Support & Metal & Incorpor. Method & $\begin{array}{l}\text { Continuous Flow } \\
\quad\left(\mathrm{mL} \cdot \mathrm{min}^{-1}\right)\end{array}$ & $\begin{array}{c}\mathrm{BrO}_{3}-\text { Initial } \\
\left(\mathrm{mmol} \cdot \mathrm{L}^{-1}\right)\end{array}$ & $\begin{array}{l}\text { Constant } \\
\text { Efficiency }\end{array}$ & Ref. \\
\hline \multirow{2}{*}{$\mathrm{Al}_{2} \mathrm{O}_{3}$} & \multirow{2}{*}{$\operatorname{Pd}(1.0 \%)$} & \multirow{2}{*}{ spraying } & \multirow{2}{*}{$14 \mathrm{~mL} \cdot \mathrm{min}^{-1}$} & 0.078 & $\begin{array}{c}100 \% \\
\text { for } 60 \mathrm{~h}\end{array}$ & \multirow{2}{*}[72]{} \\
\hline & & & & 0.0004 & $\begin{array}{c}100 \% \\
\text { for } 10 \text { days }\end{array}$ & \\
\hline $\begin{array}{l}\text { Activated carbon fibers } \\
\text { coating sintered metal } \\
\text { fibers (CNF/SMFs) }\end{array}$ & $\mathrm{Pd}(0.3 \%)$ & impregnation & $5 \mathrm{~mL} \cdot \mathrm{min}^{-1}$ & 0.39 & $\begin{array}{c}80 \% \\
\text { for } 40 \mathrm{~h}\end{array}$ & {$[70,81]$} \\
\hline $\begin{array}{l}\text { Activated carbon fibers } \\
\text { coating cordierite } \\
\text { monoliths }\end{array}$ & $\mathrm{Pd}(0.3 \%)$ & adsorption & $5 \mathrm{~mL} \cdot \mathrm{min}^{-1}$ & 0.39 & $\begin{array}{c}75 \% \\
\text { for } 40 \mathrm{~h}\end{array}$ & [85] \\
\hline $\begin{array}{c}\text { Carbon nanofibers over } \\
\text { carbon felt } \\
(\mathrm{CNF} / \mathrm{CF})\end{array}$ & $\mathrm{Pd}(0.3 \%)$ & impregnation & $5 \mathrm{~mL} \cdot \min ^{-1}$ & 0.39 & $\begin{array}{c}60 \% \\
\text { for } 40 \mathrm{~h}\end{array}$ & \multirow{2}{*}{ [15] } \\
\hline $\begin{array}{c}\text { Carbon nanofibers over } \\
\text { metal fibers } \\
\text { (CNF/SMF) }\end{array}$ & $\mathrm{Pd}(0.3 \%)$ & impregnation & $5 \mathrm{~mL} \cdot \min ^{-1}$ & 0.39 & $\begin{array}{c}80 \% \\
\text { for } 40 \mathrm{~h}\end{array}$ & \\
\hline
\end{tabular}




\section{Reaction Mechanism}

Most of the researchers agree that the bromate hydrogenation reaction follows a Langmuir-Hinshelwood mechanism [61,74]. Although bromate can be partially reduced by the solved hydrogen [64], the main reduction is produced on the surface of the catalyst (Figure 7). Therefore the rate-controlling step is the adsorption of the reactants.

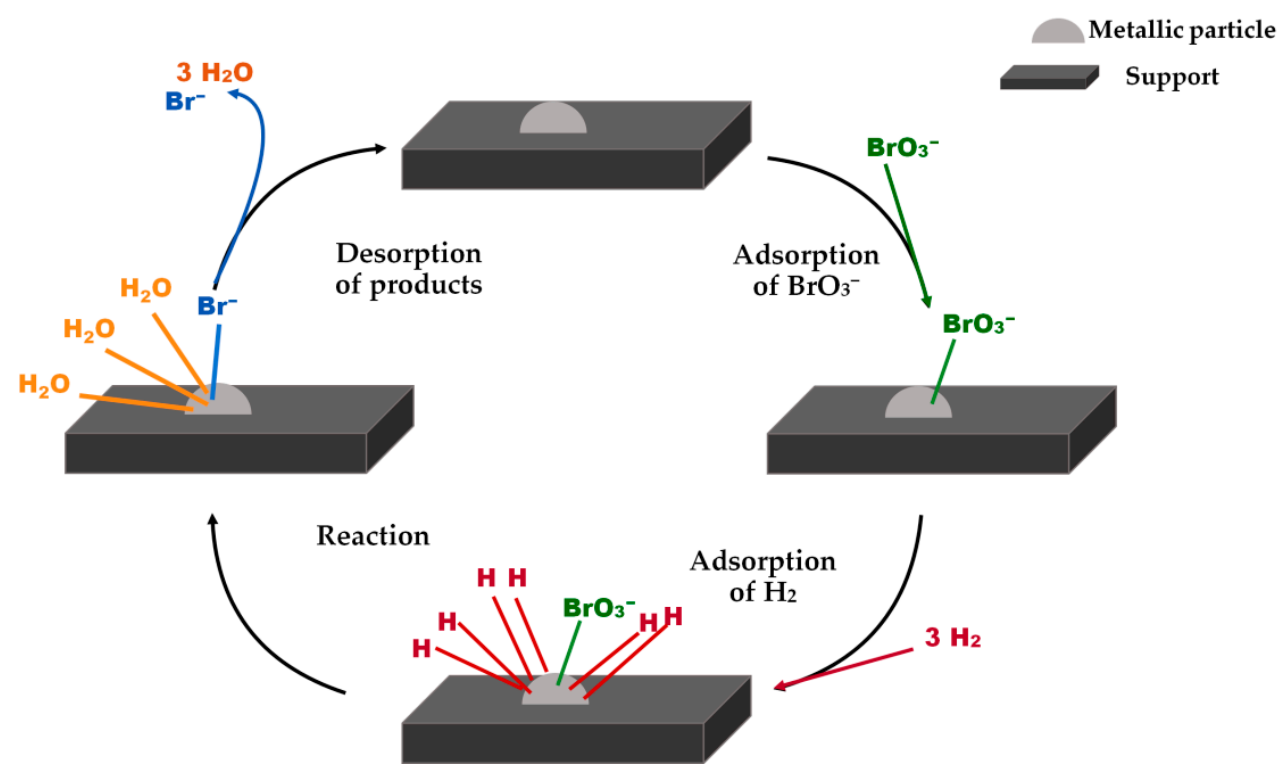

Figure 7. Langmuir-Hinshelwood mechanism for the bromate catalytic hydrogenation over supported metallic particles.

Many authors described the reaction mechanism as a dissociative adsorption of hydrogen on the surface of the metallic nanoparticles and the following reduction of neighboring adsorbed bromate anions by the dissociated hydrogen atoms [9,61,64]. Moreover, it seems that hydrogen plays a role not only on the reduction of the bromate, but also on the reduction of the metal. The continuous reduction of the metal is necessary to avoid the formation of metal-oxo species that can be generated by oxygen atoms transferred from the bromate. Therefore, hydrogen plays a dual essential role, reducing the bromates of the media and preventing the oxidation of the active metal specie [9].

Zhang et al. [62] studied the intrinsic mechanism of the reaction using Pd or Pt catalysts supported on SBA-15 mesoporous materials. They concluded that the rate-limiting step is the reduction of bromates on the metal surface rather than the diffusion or the adsorption processes. Similarly, Wang et al. [82] described the mechanism through a series of steps, involving rapid adsorption equilibrium of bromate and $\mathrm{H}_{2}$ on the surface of the catalyst, $\mathrm{H}_{2}$ dissociation by the noble metal nanoparticles to form reactive atomic hydrogen $\mathrm{H}_{\mathrm{ads}}$ and reaction of $\mathrm{H}_{\mathrm{ads}}$ with bromate. In this model, the $\mathrm{pH}$ of the media and the PZC of the catalyst surface must be considered because they can alter the mechanism and the kinetic of the reaction.

Most of the kinetic studies in the literature concluded that bromate hydrogenation is a pseudo-first-order reaction with respect to bromates, but they have not analyzed the order referred to hydrogen as it is assumed that $\mathrm{H}_{2}$ adsorption on the catalysts is much stronger than bromate adsorption [55,62]. Nevertheless, Cerrillo et al. evaluated the influence of $\mathrm{H}_{2}$ in the kinetics of the reaction by modifying the $\mathrm{H}_{2}$ partial pressure. The outcomes described a pseudo-first-order reaction with respect to both reagents [73].

All the reviewed studies showed that bromide anions are exclusively produced as the final product of the bromate hydrogenation. The reaction has a 100\% selectivity to bromide, without any byproduct formation.

The analysis of the different papers leads us to conclude that the reaction follows a Langmuir-Hinshelwood mechanism, where bromate and hydrogen are adsorbed on 
the metallic active sites. In these sites bromate and the dissociated $\mathrm{H}_{2}$ react forming bromide and water as the only reaction products. Then, all the factors favoring adsorption of bromate, i.e., positive surface charge, and/or favoring the dissociative adsorptive of hydrogen, i.e., large metallic crystal size, result in an enhancement of the catalytic activity.

\section{Influence of the Water Composition and Stability Tests}

For commercial use, it is necessary to evaluate the activity of catalysts in natural water, where many other compounds or ions are present, in order to estimate its real applicability.

As previously mentioned, $\mathrm{pH}$ is one of the most important parameters determining the activity, but also the stability of the catalysts during the catalytic removal of bromate in water phase. In general, $\mathrm{pH}$ values above the PZC of the supported catalysts repulsed the bromate ions from the catalyst surface due to its negative charge, decreasing the reaction rate $[80,82]$. Then, different catalysts, with different PZC, must be used depending on the $\mathrm{pH}$ of the water.

The influence on the catalytic activity of other substances solved in water was also studied. Thus, in the presence of other anions as $\mathrm{Cl}^{-}, \mathrm{Br}^{-}$, and $\mathrm{SO}_{4}{ }^{2-}$, the bromate reduction was more complicate. Particularly the presence of $0.6 \mathrm{mM}$ of $\mathrm{SO}_{4}{ }^{2-}$ results in the highest decrease $(75 \%)$ of the initial activity [61]. This inhibitory effect can be attributed to the competitive adsorption of the diverse anions on the active sites of the catalysts. Sulfate anion has a higher ionic charge resulting in a stronger adsorption, hindering the adsorption of bromate. Zhang et al. reported similar results [80] in a study made with distilled water containing bromate together with other anions as $\mathrm{F}^{-}, \mathrm{Cl}^{-}, \mathrm{Br}^{-}, \mathrm{NO}_{3}{ }^{-}, \mathrm{HPO}_{4}{ }^{2-}, \mathrm{SO}_{4}{ }^{2-}$, and $\mathrm{CO}_{3}{ }^{2-}$. Anions with high ionic charge and high affinition on $\mathrm{Pd}$ as $\mathrm{HPO}_{4}{ }^{2-}, \mathrm{SO}_{4}{ }^{2-}$, and $\mathrm{CO}_{3}{ }^{2-}$ caused the most noticeable inhibition effect. Other authors evaluated the effect of high charge anions such as $\mathrm{PO}_{4}{ }^{3-}$, obtaining the highest inhibitory effect [62]. On the contrary, the same study showed the bromate removal enhance when nitrate was present in the water composition at concentrations lower than $1.5 \mathrm{mM}$.

Some authors evaluated the catalytic hydrogenation of bromates using natural mineral water samples, closer to a real application. This water contains, together with the previously described anions, different cations such as $\mathrm{Ca}^{2+}, \mathrm{Na}^{+}$, or $\mathrm{Mg}^{2+}$. The studies verified that bromate can be completely removed during the water treatment even if high concentrations of different ions are present in water composition [72,81]. Nevertheless, deactivation of the catalysts appears when hard water (with high $\mathrm{Ca}^{2+}$ and $\mathrm{Mg}^{2+}$ content) is treated as the catalyst gets fouled by calcium salts deposition, hindering and blocking the catalytic active centers. This problem gets greater depending on how hard the treated water is, but this negative effect can be minimized by the incorporation of $\mathrm{CO}_{2}$ together with $\mathrm{H}_{2}$. The presence of $\mathrm{CO}_{2}$ produces a lower $\mathrm{pH}$ that avoids the precipitation of the calcium salts [81]. Analogously, other authors studied the efficiency and stability of the catalytic system using real tap water containing different ions together with bromates [71]. The catalyst is active with this water, although a longer time is necessary to achieve a complete bromate conversion (Figure 5). These results indicated that it is necessary to evaluate and design specific strategies when using real water because the different compositions and properties of water could result in a different catalytic activity.

In accordance with the complex and different nature of water, it is mandatory to employ very stable catalysts able to be active in diverse scenarios. Zhang et al. [62] investigated the reutilization of the catalyst $(4 \% \mathrm{Pt} / \mathrm{SBA}-15)$ by repeated experiments under the same conditions. In five reaction cycles, around $8 \%$ of activity was lost and this decrease was attributed to a small leaching of the active metal. Similarly, Freitas et al. [69] did not highlight any deactivation of the catalyst after 3 cycles, but they also reported some metal leaching.

However, for a proper stability study, catalysts must be tested using a continuous reactor. Gao et al. [72] report that Pd catalyst can be active till 10 days using natural mineral water, although it contained various competitive ions at elevated concentrations and residual ozone. Similarly, using diverse approaches of Pd-based catalysts, Palomares et al. [81,85] 
demonstrated the efficiency of this catalytic removal system using different continuous reactors and using diverse water (natural water or industrial wastewater). The possibility of using the catalytic hydrogenation to remove bromate from industrially polluted water with a high quantity of pollutants was also evaluated by this research group [81]. Compared to natural water, the catalytic activity of the evaluated Pd-catalyst was lower, but constant along the reaction. These results evidence the stability of the catalyst and the noteworthy influence of the type of water.

A cradle-to-gate life cycle assessment (LCA) study showed the potential of this technology and identified the areas for future optimization of this novel technology [15]. The study showed that in a potential water purification process based on catalytic reduction of bromates, the Pd catalyst supported on carbon nanofibers grown on sintered metal fibers is considerably more efficient in terms of activity, cost, and environmental impact. It also showed that catalytic reduction of bromates using $\mathrm{H}_{2}$ is a potentially attractive option for a water purification process in terms of sustainability compared to conventional technologies.

From the review of the scientific articles, it can be concluded that Pd catalysts are active and stable when they are used with polluted natural or industrial water. However, it is worth mentioning that the presence of other species in the aqueous media results in a lower, but stable, activity. Moreover, it seems that the main problem that could cause the catalyst deactivation is the fouling of the catalyst surface by deposition of calcium salts. Other possible problem of this technology is the metal leaching that will depend on the selected support, the metal-support interaction, and the preparation method used to synthesize the catalyst.

\section{Conclusions}

The final aim of this study is to stablish the necessary characteristics to design an active catalyst for the bromate hydrogenation reaction. From the review of the literature, it can be concluded that mainly noble metals ( $\mathrm{Pd}$ or $\mathrm{Pt}$ ) are necessary to design active catalysts as they are able to activate hydrogen at room temperature and atmospheric pressure. Those noble metals must be supported on a material that favors reactants adsorption and interaction. In this sense, mesoporous supports with positive surface charge seem to be the most convenient option. It was also described that large metallic particles are more active than small metallic crystallites, but the presence of large particles result on a low metal dispersion, wasting an important quantity of noble metal, then a compromise between large metallic crystallites and dispersion must be obtained in order to have an active catalyst.

The main strength of this technique is that the catalysts described in the literature seem to be active using different types of water (although the activity decreases), being stable and selective. It was shown that they can be used in continuous reactors and that combined with a non-noble metal can be even active for the removal of other oxyanions pollutants present in water as nitrates.

The weakness of this technique is the cost of the noble metals, for that reason the research on the use of other cheaper metals must be enhanced. Those metals will be less active, but if they are able to catalyze the reaction, its use will be preferred. Another weakness is the decrease of the activity in the presence of other ions and all the problems related with mass transfer processes that usually appear in solid-liquid-gas reaction systems. For that reason, more research in the use of different supports that favors reactantactive sites interaction is necessary. In this sense, chemical engineering must also play a role in order to design effective reactors able to treat a high flow of polluted water with a supported catalyst, minimizing the use of hydrogen. Life cycle analysis of the optimized process is necessary for a final implementation of this technique.

The analysis of the literature made in this review may conclude that catalytic hydrogenation seems to be an efficient method to treat bromate-polluted water. This technique may compete with other more standard separation techniques (membranes) as it does not 
generate waste and has a lower energetic cost. Nevertheless, more research in this topic is still necessary in order to find cheaper and stable catalysts.

Author Contributions: Investigation, J.L.C. and A.E.P.; writing-original draft preparation, J.L.C. and A.E.P.; writing-review and editing, J.L.C. and A.E.P. All authors have read and agreed to the published version of the manuscript.

Funding: This research was funded by the Spanish Ministry of Economy and Competitiveness (MINECO/FEDER), projects RTI2018-101784-B-I00.

Conflicts of Interest: The authors declare no conflict of interest.

\section{References}

1. Armor, J.N. Environmental catalysis. Appl. Catal. B Environ. 1992, 1, 221-256. [CrossRef]

2. Armor, J. Catalytic solutions to reduce pollutants. Catal. Today 1997, 38, 163-167. [CrossRef]

3. Moreno-González, M.; Blasco, T.; Góra-Marek, K.; Palomares, A.; Corma, A. Study of propane oxidation on Cu-zeolite catalysts by in-situ EPR and IR spectroscopies. Catal. Today 2014, 227, 123-129. [CrossRef]

4. Cucciniello, R.; Intiso, A.; Siciliano, T.; Palomares, A.E.; Martínez-Triguero, J.; Cerrillo, J.L.; Proto, A.; Rossi, F. Oxidative Degradation of Trichloroethylene over $\mathrm{Fe}_{2} \mathrm{O}_{3}$-doped Mayenite: Chlorine Poisoning Mitigation and Improved Catalytic Performance. Catalysts 2019, 9, 747. [CrossRef]

5. Ibrahim, M.; Labaki, M.; Giraudon, J.-M.; Lamonier, J.-F. Hydroxyapatite, a multifunctional material for air, water and soil pollution control: A review. J. Hazard. Mater. 2020, 383, 121139. [CrossRef]

6. Zhang, N.; Ye, C.; Yan, H.; Li, L.; He, H.; Wang, D.; Li, Y. Single-atom site catalysts for environmental catalysis. Nano Res. 2020, 13, 1-18. [CrossRef]

7. Jablonska, M.; Palomares Gimeno, A.E.; Wegrzyn, A.; Chmielarz, L. A short review about NOx storage/reduction catalysts based on metal oxides and hydrotalcite-type anionic clays. Acta Geodyn. Geomater. 2014, 11, 175-186. [CrossRef]

8. Blanch-Raga, N.; Palomares, A.E.; Martínez-Triguero, J.; Puche, M.; Fetter, G.; Bosch, P. The oxidation of trichloroethylene over different mixed oxides derived from hydrotalcites. Appl. Catal. B Environ. 2014, 160, 129-134. [CrossRef]

9. Chaplin, B.P.; Reinhard, M.; Schneider, W.F.; Schuth, C.; Shapley, J.R.; Strathmann, T.J.; Werth, C.J. Critical Review of Pd-Based Catalytic Treatment of Priority Contaminants in Water. Environ. Sci. Technol. 2012, 46, 3655-3670. [CrossRef]

10. Hu, M.; Liu, Y.; Yao, Z.; Ma, L.; Wang, X. Catalytic reduction for water treatment. Front. Environ. Sci. Eng. 2018, 12, 3. [CrossRef]

11. Yin, Y.B.; Guo, S.; Heck, K.N.; Clark, C.A.; Coonrod, C.L.; Wong, M.S. Treating water by degrading oxyanions using metallic nanostructures. Acs Sustain. Chem. Eng. 2018, 6, 11160-11175. [CrossRef]

12. Frierdich, A.J.; Shapley, J.R.; Strathmann, T.J. Rapid reduction of N-nitrosamine disinfection byproducts in water with hydrogen and porous nickel catalysts. Environ. Sci. Technol. 2008, 42, 262-269. [CrossRef] [PubMed]

13. Sekhar, A.S.; Zaki, A.; Troncea, S.; Casale, S.; Vinod, C.; Dacquin, J.; Granger, P. Enhanced selectivity of 3-D ordered macroporous $\mathrm{Pt} / \mathrm{Al} 2 \mathrm{O} 3$ catalysts in nitrites removal from water. Appl. Catal. A Gen. 2018, 564, 26-32. [CrossRef]

14. Palomares, A.; Franch, C.; Corma, A. A study of different supports for the catalytic reduction of nitrates from natural water with a continuous reactor. Catal. Today 2011, 172, 90-94. [CrossRef]

15. Yaseneva, P.; Marti, C.F.; Palomares, E.; Fan, X.; Morgan, T.; Perez, P.S.; Ronning, M.; Huang, F.; Yuranova, T.; Kiwi-Minsker, L. Efficient reduction of bromates using carbon nanofibre supported catalysts: Experimental and a comparative life cycle assessment study. Chem. Eng. J. 2014, 248, 230-241. [CrossRef]

16. Butler, R.; Godley, A.; Lytton, L.; Cartmell, E. Bromate environmental contamination: Review of impact and possible treatment. Crit. Rev. Environ. Sci. Technol. 2005, 35, 193-217. [CrossRef]

17. IARC. Potassium Bromate (Summary of Data Reported and Evaluation); International Agency for Research on Cancer: Lyon, France, 1999.

18. McCann, B. By-products blues. Water 1999, 21, 15-18.

19. von Gunten, U. Ozonation of drinking water: Part II. Disinfection and by-product formation in presence of bromide, iodide or chlorine. Water Res. 2003, 37, 1469-1487. [CrossRef]

20. von Gunten, U. The basics of oxidants in water treatment. Part B: Ozone reactions. Water Sci. Technol. 2007, 55, 25-29. [CrossRef]

21. Buffle, M.O.; Galli, S.; von Gunten, U. Enhanced Bromate Control during Ozonation: The Chlorine-Ammonia Process. Environ. Sci. Technol. 2004, 38, 5187-5195. [CrossRef]

22. Pinkernell, U.; von Gunten, U. Bromate Minimization during Ozonation: Mechanistic Considerations. Environ. Sci. Technol. 2001, 35, 2525-2531. [CrossRef]

23. Song, R.; Minear, R.; Westerhoff, P.; Amy, G. Bromate formation and control during water ozonation. Environ. Technol. 1996, 17, 861-868. [CrossRef]

24. Siddiqui, M.S.; Amy, G.L. Factors affecting DBP Formation during ozone-bromine reactions. J. Am. Water Work. Assoc. 1993, 85, 63-72. [CrossRef]

25. Prados-Ramirez, M.; Ciba, N.; Bourbigot, M.M. Available techniques for reducing bromate in drinking water. Water Supply 1995, 13, 61-70. 
26. Zeino, A.; Abulkibash, A.; Khaled, M.; Atieh, M. Bromate removal from water using doped iron nanoparticles on multiwalled carbon nanotubes (CNTS). J. Nanomater. 2014. [CrossRef]

27. Bhatnagar, A.; Choi, Y.-H.; Yoon, Y.-J.; Shin, Y.; Jeon, B.-H.; Kang, J.-W. Bromate removal from water by granular ferric hydroxide (GFH). J. Hazard. Mater. 2009, 170, 134-140. [CrossRef]

28. Liu, G.; You, S.; Zhang, Y.; Huang, H.; Spanjers, H. Conjugated donor-acceptor (DA) supramolecule catalyst for visible-light-driven photocatalytic removal of bromate in water. J. Colloid Interface Sci. 2019, 553, 666-673. [CrossRef]

29. van Ginkel, C.G.; van Haperen, A.M.; van der Togt, B. Reduction of bromate to bromide coupled to acetate oxidation by anaerobic mixed microbial cultures. Water Res. 2005, 39, 59-64. [CrossRef]

30. Lin, D.; Liang, H.; Li, G. Factors affecting the removal of bromate and bromide in water by nanofiltration. Environ. Sci. Pollut. Res. 2020, 27, 24639-24649. [CrossRef]

31. Han, P.; Xia, Y. Thiol-functionalized metal-organic framework for highly efficient removal of bromate from water. J. Environ. Chem. Eng. 2018, 6, 3384-3391. [CrossRef]

32. Siddiqui, M.; Amy, G.; Ozekin, K.; Zhai, W.; Westerhoff, P. Alternative strategies for removing bromate. J. Am. Water Work. Assoc. 1994, 86, 81-96. [CrossRef]

33. Gordon, G.; Gauw, R.D.; Emmert, G.L.; Walters, B.D.; Bubnis, B. Treatment technologies: Chemical reduction methods for bromate ion removal. J. Am. Water Work. Assoc. 2002, 94, 91-98. [CrossRef]

34. Xie, L.; Shang, C. Effects of copper and palladium on the reduction of bromate by Fe(0). Chemosphere 2006, 64, 919-930. [CrossRef] [PubMed]

35. Zhang, H.; Deng, R.; Wang, H.; Kong, Z.; Dai, D.; Jing, Z.; Jiang, W.; Hou, Y. Reduction of bromate from water by zero-valent iron immobilized on functional polypropylene fiber. Chem. Eng. J. 2016, 292, 190-198. [CrossRef]

36. Chiu, Y.-T.; Lee, P.-Y.; Wi-Afedzi, T.; Lee, J.; Lin, K.-Y.A. Elimination of bromate from water using aluminum beverage cans via catalytic reduction and adsorption. J. Colloid Interface Sci. 2018, 532, 416-425. [CrossRef]

37. Lin, K.-Y.A.; Lin, C.-H.; Yang, H. Enhanced bromate reduction using zero-valent aluminum mediated by oxalic acid. J. Environ. Chem. Eng. 2017, 5, 5085-5090. [CrossRef]

38. Hamid, S.; Abudanash, D.; Han, S.; Kim, J.R.; Lee, W. Strategies to enhance the stability of nanoscale zero-valent iron (NZVI) in continuous BrO3- reduction. J. Environ. Manag. 2019, 231, 714-725. [CrossRef]

39. Westerhoff, P. Reduction of Nitrate, Bromate, and Chlorate by Zero Valent Iron (Feo). J. Environ. Eng. 2003, 129, 10-16. [CrossRef]

40. Wang, L.; Zhang, J.; Liu, J.; He, H.; Yang, M.; Yu, J.; Ma, Z.; Jiang, F. Removal of bromate ion using powdered activated carbon. J. Environ. Sci. 2010, 22, 1846-1853. [CrossRef]

41. Mustapha, C.; Benamar, D. Comparison of the bromate ions removal by nanofiltration membranes made from different polymers at different conditions. Chem. Rev. Lett. 2019, 2, 118-122.

42. Gyparakis, S.; Diamadopoulos, E. Formation and reverse osmosis removal of bromate ions during ozonation of groundwater in coastal areas. Sep. Sci. Technol. 2007, 42, 1465-1476. [CrossRef]

43. Wisniewski, J.A.; Kabsch-Korbutowicz, M.; Lakomska, S. Removal of bromate ions from water in the processes with ion-exchange membranes. Sep. Purif. Technol. 2015, 145, 75-82. [CrossRef]

44. Matos, C.T.; Velizarov, S.; Reis, M.A.M.; Crespo, J.G. Removal of Bromate from Drinking Water Using the Ion Exchange Membrane Bioreactor Concept. Environ. Sci. Technol. 2008, 42, 7702-7708. [CrossRef] [PubMed]

45. Siddiqui, M.S.; Amy, G.L.; Cooper, W.J.; Kurucz, C.N.; Waite, T.D.; Nickelsen, M.G. Bromate ion removal by HEEB irradiation. J. Am. Water Work. Assoc. 1996, 88, 90-101. [CrossRef]

46. Siddiqui, M.; Amy, G.; Zhai, W.; McCollum, L. Removal of bromate after ozonation during drinking water treatment. In Disinfection By-Products in Water Treatment. The Chemistry of Their Formation and Control; Minear, A., Amy, G., Eds.; CRC Press: Boca Raton, FL, USA, 1995; p. 520.

47. Noguchi, H.; Nakajima, A.; Watanabe, T.; Hashimoto, K. Removal of bromate ion from water using $\mathrm{TiO}_{2}$ and alumina-loaded $\mathrm{TiO}_{2}$ photocatalysts. Water Sci. Technol. 2002, 46, 27-31. [CrossRef]

48. Noguchi, H.; Nakajima, A.; Watanabe, T.; Hashimoto, K. Design of a photocatalyst for bromate decomposition: Surface modification of $\mathrm{TiO}_{2}$ by pseudo-boehmite. Environ. Sci. Technol. 2003, 37, 153-157. [CrossRef]

49. Cunha, G.S.; Santos, S.G.; Souza-Chaves, B.M.; Silva, T.F.; Bassin, J.P.; Dezotti, M.W.; Boaventura, R.A.; Dias, M.M.; Lopes, J.C.B.; Vilar, V.J. Removal of bromate from drinking water using a heterogeneous photocatalytic mili-reactor: Impact of the reactor material and water matrix. Environ. Sci. Pollut. Res. 2019, 26, 33281-33293. [CrossRef]

50. Zhang, Y.; Li, L.; Liu, H.; Lu, T. Graphene oxide and $\mathrm{F}$ co-doped $\mathrm{TiO}_{2}$ with $(001)$ facets for the photocatalytic reduction of bromate: Synthesis, characterization and reactivity. Chem. Eng. J. 2017, 307, 860-867. [CrossRef]

51. Zhao, X.; Zhang, G.; Zhang, Z. $\mathrm{TiO}_{2}$-based catalysts for photocatalytic reduction of aqueous oxyanions: State-of-the-art and future prospects. Environ. Int. 2020, 136, 105453. [CrossRef]

52. Hijnen, W.A.M.; Voogt, R.; Veenendaal, H.R.; van der Jagt, H.; van der Kooij, D. Bromate reduction by denitrifying bacteria. Appl. Environ. Microbiol. 1995, 61, 239-244. [CrossRef]

53. Duonghong, D.; Erbs, W.; Shuben, L.; Grätzel, M. Efficient redox catalysis by $\mathrm{RuO}_{2}$ in the generation of oxygen and bromine from aqueous bromate solutions. Chem. Phys. Lett. 1983, 95, 266-268. [CrossRef]

54. Dong, Z.; Dong, W.; Sun, F.; Zhu, R.; Ouyang, F. Effects of preparation conditions on catalytic activity of Ru/AC catalyst to reduce bromate ion in water. React. Kinet. Mech. Catal. 2012, 107, 231-244. [CrossRef] 
55. Dong, Z.; Sun, F.; Dong, W.; Jiang, C. Catalytic bromate removal from water by using activated carbon supported with ruthenium (AC/Ru) catalyst. Environ. Eng. Sci. 2018, 35, 176-184. [CrossRef]

56. Pintar, A.; Batista, J.; Levec, J. Catalytic denitrification: Direct and indirect removal of nitrates from potable water. Catal. Today 2001, 66, 503-510. [CrossRef]

57. Yuranova, T.; Franch, C.; Palomares, A.; Garcia-Bordejé, E.; Kiwi-Minsker, L. Structured fibrous carbon-based catalysts for continuous nitrate removal from natural water. Appl. Catal. B Environ. 2012, 123, 221-228. [CrossRef]

58. Thakur, D.B.; Tiggelaar, R.M.; Weber, Y.; Gardeniers, J.G.E.; Lefferts, L.; Seshan, K. Ruthenium catalyst on carbon nanofiber support layers for use in silicon-based structured microreactors. Part II: Catalytic reduction of bromate contaminants in aqueous phase. Appl. Catal. B 2011, 102, 243-250. [CrossRef]

59. Andrew Lin, K.-Y.; Chen, S.-Y. Bromate reduction in water by catalytic hydrogenation using metal-organic frameworks and sodium borohydride. RSC Adv. 2015, 5, 43885-43896. [CrossRef]

60. Lin, K.-Y.A.; Chen, S.-Y. Catalytic Reduction of Bromate Using ZIF-Derived Nanoscale Cobalt/Carbon Cages in the Presence of Sodium Borohydride. ACS Sustain. Chem. Eng. 2015, 3, 3096-3103. [CrossRef]

61. Chen, $\mathrm{H} . ; \mathrm{Xu}, \mathrm{Z}$; Wan, H.; Zheng, J.; Yin, D.; Zheng, S. Aqueous bromate reduction by catalytic hydrogenation over $\mathrm{Pd} / \mathrm{Al}_{2} \mathrm{O}_{3}$ catalysts. Appl. Catal. B 2010, 96, 307-313. [CrossRef]

62. Zhang, Z.; Luo, Y.; Guo, Y.; Shi, W.; Wang, W.; Zhang, B.; Zhang, R.; Bao, X.; Wu, S.; Cui, F. Pd and Pt nanoparticles supported on the mesoporous silica molecular sieve SBA-15 with enhanced activity and stability in catalytic bromate reduction. Chem. Eng. J. 2018, 344, 114-123. [CrossRef]

63. Chen, X.; Huo, X.; Liu, J.; Wang, Y.; Werth, C.J.; Strathmann, T.J. Exploring beyond palladium: Catalytic reduction of aqueous oxyanion pollutants with alternative platinum group metals and new mechanistic implications. Chem. Eng. J. 2017, 313, 745-752. [CrossRef]

64. Restivo, J.; Soares, O.S.G.P.; Orfao, J.J.M.; Pereira, M.F.R. Metal assessment for the catalytic reduction of bromate in water under hydrogen. Chem. Eng. J. 2015, 263, 119-126. [CrossRef]

65. Franch, C.; Rodríguez-Castellón, E.; Reyes-Carmona, Á.; Palomares, A.E. Characterization of ( $\mathrm{Sn}$ and Cu)/Pd catalysts for the nitrate reduction in natural water. Appl. Catal. A Gen. 2012, 425, 145-152. [CrossRef]

66. Barrabés, N.; Just, J.; Dafinov, A.; Medina, F.; Fierro, J.; Sueiras, J.; Salagre, P.; Cesteros, Y. Catalytic reduction of nitrate on Pt-Cu and Pd-Cu on active carbon using continuous reactor: The effect of copper nanoparticles. Appl. Catal. B Environ. 2006, 62, 77-85. [CrossRef]

67. Restivo, J.; Soares, O.S.G.P.; Orfao, J.J.M.; Pereira, M.F.R. Bimetallic activated carbon supported catalysts for the hydrogen reduction of bromate in water. Catal. Today 2015, 249, 213-219. [CrossRef]

68. Soares, O.S.G.P.; Freitas, C.M.A.S.; Fonseca, A.M.; Orfao, J.J.M.; Pereira, M.F.R.; Neves, I.C. Bromate reduction in water promoted by metal catalysts prepared over faujasite zeolite. Chem. Eng. J. 2016, 291, 199-205. [CrossRef]

69. Freitas, C.M.A.S.; Soares, O.S.G.P.; Orfao, J.J.M.; Fonseca, A.M.; Pereira, M.F.R.; Neves, I.C. Highly efficient reduction of bromate to bromide over mono and bimetallic ZSM5 catalysts. Green Chem. 2015, 17, 4247-4254. [CrossRef]

70. Yuranova, T.; Kiwi-Minsker, L.; Franch, C.; Palomares, A.E.; Armenise, S.; Garcia-Bordeje, E. Nanostructured Catalysts for the Continuous Reduction of Nitrates and Bromates in Water. Ind. Eng. Chem. Res. 2013, 52, 13930-13937. [CrossRef]

71. Chen, Y.; Yang, W.; Gao, S.; Gao, Y.; Sun, C.; Li, Q. Catalytic reduction of aqueous bromate by a non-noble metal catalyst of CoS 2 hollow spheres in drinking water at room temperature. Sep. Purif. Technol. 2020, 251, 117353. [CrossRef]

72. Gao, Y.; Sun, W.; Yang, W.; Li, Q. Creation of $\mathrm{Pd} / \mathrm{Al}_{2} \mathrm{O}_{3}$ Catalyst by a Spray Process for Fixed Bed Reactors and Its Effective Removal of Aqueous Bromate. Sci. Rep. Nat. 2017, 7, 41797. [CrossRef]

73. Cerrillo, J.L.; Lopes, C.W.; Rey, F.; Agostini, G.; Kiwi-Minsker, L.; Palomares, A.E. Nature and evolution of Pd catalysts supported on activated carbon fibers during the catalytic reduction of bromate in water. Catal. Sci. Technol. 2020, 10, 3646-3653. [CrossRef]

74. Sun, J.; Zhang, J.; Fu, H.; Wan, H.; Wan, Y.; Qu, X.; Xu, Z.; Yin, D.; Zheng, S. Enhanced catalytic hydrogenation reduction of bromate on Pd catalyst supported on $\mathrm{CeO}_{2}$ modified SBA-15 prepared by strong electrostatic adsorption. Appl. Catal. B 2018, 229, 32-40. [CrossRef]

75. Sun, W.; Li, Q.; Gao, S.; Shang, J.K. Highly efficient catalytic reduction of bromate in water over a quasi-monodisperse, superparamagnetic Pd/ $\mathrm{Fe}_{3} \mathrm{O}_{4}$ catalyst. J. Mater. Chem. A 2013, 1, 9215-9224. [CrossRef]

76. Chen, H.; Zhang, P.; Tan, W.; Jiang, F.; Tang, R. Palladium supported on amino functionalized magnetic MCM-41 for catalytic hydrogenation of aqueous bromate. RSC Adv. 2014, 4, 38743-38749. [CrossRef]

77. Cerrillo, J.L.; Lopes, C.W.; Rey, F.; Palomares, A.E. The Influence of the Support Nature and the Metal Precursor in the Activity of Pd-based Catalysts for the Bromate Reduction Reaction. ChemCatChem 2021, 13, 1230-1238. [CrossRef]

78. Perez-Coronado, A.M.; Soares, O.S.G.P.; Calvo, L.; Rodriguez, J.J.; Gilarranz, M.A.; Pereira, M.F.R. Catalytic reduction of bromate over catalysts based on Pd nanoparticles synthesized via water-in-oil microemulsion. Appl. Catal. B 2018, 237, 206-213. [CrossRef]

79. Restivo, J.; Soares, O.S.G.P.; Orfao, J.M.J.; Pereira, M.F.R. Catalytic reduction of bromate over monometallic catalysts on different powder and structured supports. Chem. Eng. J. 2017, 309, 197-205. [CrossRef]

80. Zhang, P.; Jiang, F.; Chen, H. Enhanced catalytic hydrogenation of aqueous bromate over Pd/mesoporous carbon nitride. Chem. Eng. J. 2013, 234, 195-202. [CrossRef] 
81. Palomares, A.E.; Franch, C.; Yuranova, T.; Kiwi-Minsker, L.; Garcia-Bordeje, E.; Derrouiche, S. The use of Pd catalysts on carbon-based structured materials for the catalytic hydrogenation of bromates in different types of water. Appl. Catal. B 2014, 146, 186-191. [CrossRef]

82. Wang, Y.; Liu, J.; Wang, P.; Werth, C.J.; Strathmann, T.J. Palladium Nanoparticles Encapsulated in Core-Shell Silica: A Structured Hydrogenation Catalyst with Enhanced Activity for Reduction of Oxyanion Water Pollutants. Acs Catal. 2014, 4, 3551-3559. [CrossRef]

83. Li, M.; Zhou, X.; Sun, J.; Fu, H.; Qu, X.; Xu, Z.; Zheng, S. Highly effective bromate reduction by liquid phase catalytic hydrogenation over Pd catalysts supported on core-shell structured magnetites: Impact of shell properties. Sci. Total Environ. 2019, 663, 673-685. [CrossRef] [PubMed]

84. Zhang, Z.; Cheng, J.; Luo, Y.; Shi, W.; Wang, W.; Zhang, B.; Zhang, R.; Bao, X.; Guo, Y.; Cui, F. Pt nanoparticles supported on amino-functionalized SBA-15 for enhanced aqueous bromate catalytic reduction. Catal. Commun. 2018, 105, 11-15. [CrossRef]

85. Marco, Y.; Garcia-Bordeje, E.; Franch, C.; Palomares, A.E.; Yuranova, T.; Kiwi-Minsker, L. Bromate catalytic reduction in continuous mode using metal catalysts supported on monoliths coated with carbon nanofibers. Chem. Eng. J. 2013, 230, 605-611. [CrossRef]

86. Amali, A.J.; Rana, R.K. Stabilisation of $\mathrm{Pd}(0)$ on surface functionalised $\mathrm{Fe}_{3} \mathrm{O}_{4}$ nanoparticles: Magnetically recoverable and stable recyclable catalyst for hydrogenation and Suzuki-Miyaura reactions. Green Chem. 2009, 11, 1781-1786. [CrossRef]

87. Sandoval, V.H.; Gigola, C.E. Characterization of $\mathrm{Pd}$ and $\mathrm{Pd}-\mathrm{Pb} / \alpha-\mathrm{Al}_{2} \mathrm{O}_{3}$ catalysts. A TPR-TPD study. Appl. Catal. A Gen. 1996, 148, 81-96. [CrossRef]

88. Lopes, C.W.; Cerrillo, J.L.; Palomares, A.E.; Rey, F.; Agostini, G. An in situ XAS study of the activation of precursor-dependent Pd nanoparticles. Phys. Chem. Chem. Phys. 2018, 20, 12700-12709. [CrossRef] [PubMed] 